\title{
David Clarke, Chinese Art and Its Encounter with the
}

World,

Hong Kong, Hong Kong University Press, 2011, 259 pp.

\section{Nicolas Idier}

Translator. N. Jayaram

\section{(2) OpenEdition}

\section{Journals}

Electronic version

URL: http://journals.openedition.org/chinaperspectives/6411

DOI: 10.4000/chinaperspectives.6411

ISSN: 1996-4617

\section{Publisher}

Centre d'étude français sur la Chine contemporaine

\section{Printed version}

Date of publication: 1 March 2014

Number of pages: $75-77$

ISSN: 2070-3449

\section{Electronic reference}

Nicolas Idier, « David Clarke, Chinese Art and Its Encounter with the World, », China Perspectives [Online], 2014/1 | 2014, Online since 01 January 2017, connection on 24 September 2020. URL : http:// journals.openedition.org/chinaperspectives/6411; DOI : https://doi.org/10.4000/chinaperspectives. 6411

This text was automatically generated on 24 September 2020.

(c) All rights reserved 


\section{David Clarke, Chinese Art and Its Encounter with the World,}

Hong Kong, Hong Kong University Press, 2011, 259 pp.

\section{Nicolas Idier}

Translation : N. Jayaram

David Clarke is founder and scientific director of Hong Kong Art Archive, a database of use to art historians and collectors, critics, advertisers, and gallery owners. With his diverse activities (he has been part of the Hong Kong Arts Development Council and Hong Kong Arts Centre, currently chairing the academic committee of the Centre's Hong Kong Art School; he is also a photographer), Clarke envisages the art world in three main dimensions: artistic creation, academic research, and administration of its promotion. All this imparts a special richness to this compilation of six of his articles, some previously published in exhibition catalogues, collective works, and specialised journals between 2005 and 2010. Apart from this, Clarke lives in the

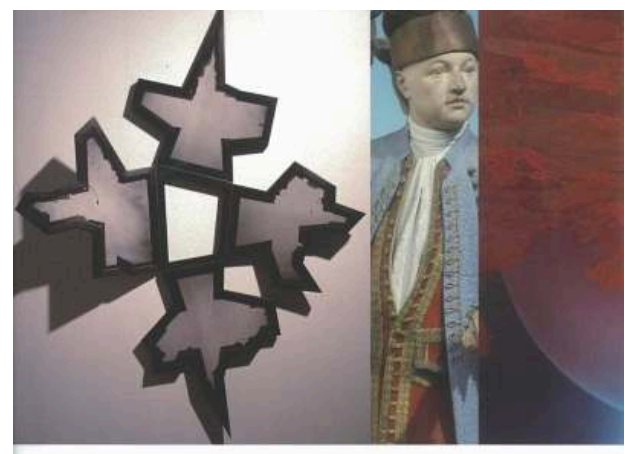

Chinese Art and Daxidcare Its Encounter with the World

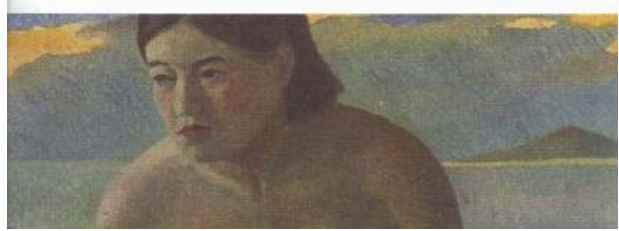
heartland of the object of his investigation. Such proximity nurtures a form of empathy he seeks and that does seem to be a necessary quality for the discipline of art history, which cannot be divorced from frequent familiarity with the subject of study. This triple quality - scientific, public, and artistic - opens up enlarged perspectives. The coming together of different forms of art helps engender a non-formalist art history without, however, losing sight 
of the visual objects. This has become necessary as art history in the modern and contemporary era has gotten more complex, notably because of the acceleration of exchanges and multiplication of screens and cross references. When images circulate much faster than texts, does it mean no translation is needed? Certainly not, as they operate in a complex environment, something Clarke alludes to: the process of cultural transfer, resistance, and imitation, as well as of ingestion, has been at work between China and the West ever since the first contact.

2 While it might be regrettable that the book's title suggests too vast a canvas, as is often the case with collections of articles or pre-published contributions, what is important is that each chapter is perfectly laid out and gives the reader the keys to understanding the subjects of specific issues: Chinese artist Chitqua, who lived in London in the eighteenth century, and then the relations between Teng Baiye and Mark Tobey during a crucial era in Chinese aesthetic modernity (the 1920s), constitute the first part, entitled "Trajectories"; the second part is devoted to two recurring issues representation of the body and abstraction; the third and last part focuses on two cities wedged "between China and the world" - Macao and Hong Kong. Clarke thus envisages major axes of art history in the spectrum of cultural history: artists, concepts, and places. Formal analysis of some works helps synthesise the conjunction of these three axes without recourse to excessive structuralism. While the author says his work benefits from a "multi focal" approach (introduction, p. 5), everything seems set to stress the importance of place of production and reception, of the work, concept, and artist.

3 First, Chitqua in eighteenth century London: through a focus on this sculptor and modeller, Clarke expounds on Chinese art in its least noble angle - craft and anecdote, as opposed to literary arts that generally monopolised international and Chinese exhibitions. Pierre Ryckmans had opted for a similar approach, devoting a monograph to Su Renshan, a little-known nineteenth century Guangdong painter. ${ }^{1}$ Chitqua's travels necessitate a narration that Clarke reconstructs - from Guangdong to London, where he arrived in 1769 and departed from in 1772 (he could not stand the British climate), well-versed in English, a Chinese art expert sought out by British collectors and introduced to London's high society, where his art became a sensation. While untangling Chitqua's career, Clarke explores a great diversity of sources: gazettes from the era, personal diaries, and paintings. This visual enquiry is usefully reconstituted through a high-quality iconography, leading to the author's first conclusion: Chinese artists' mobility, which today is one of the main motors of globalised contemporary art, began quite early, with often little-known personalities such as Chitqua, "a pioneering example," first in a genealogy that Clarke pursues in the rest of the book: Teng Baiye, Zao Wou-ki, Lin Fengmian, and Li Tiefu.

4 After examining the career of an eighteenth-century artist, Clarke turns to the relations between two artists considered the masters of aesthetic modernity in Chinese and Western modernity respectively: Teng Baiye (1900-1980) and Mark Tobey (1890-1976). Tobey's “white writing" constitutes an aesthetic turning point, having influenced many contemporary artists such as Jackson Pollock and stemming at least in part from the discovery of Asian, especially Chinese, art. Tobey first met Teng in Seattle in the 1920s. Some years later Tobey went to China and pursued his study of calligraphy. Thus their careers overlapped. 
While the influence of contemporary Western art on Chinese productions throughout the twentieth century is formally acknowledged, the reciprocal influence is less well known. Without a doubt, the major merit of Clarke's book is that it shows, using precise and documented examples, the inter-penetration of the Chinese and Western art scenes, and the reciprocity of influences. The reader will appreciate the importance attached to the first-rate linguistic analysis, especially problems of phonetic transcriptions of Chinese patronyms. This is not an anecdotal issue, as it conditioned sources at the time. Take Teng Baiye, for instance: art history books in English flounder among “T'eng Kwei," “Teng Kuei," “Teng Kroei," “Teng Quay” and even "Kwei Dun," for Teng Baiye's real name, Teng Gui. This example is cited in order to highlight another quality of Clarke's work: getting the reader's feet muddied in the methodology and obstacles in retracing art history.

Clarke cites several accounts of artists whose careers he examines, as well as those of people they encountered, in what constitutes another form of getting the feet muddied. Take for instance the extract of a letter Tobey sent from Shanghai in 1934 to Dorothy Elmhirst, a rich American philanthropist linked to a large number of contemporary artists: "[...] the Chinese are not figure or nude conscious" (p.101). The reader discovers a considerable historical exchange process that traverses the aesthetic thought expressed by the actors. From then on, the lines of separation become less distinct and clear than might have appeared at first: while in the 1920s and 1930s Tobey experimented with calligraphy and line drawings, Teng was exploring volumes through sculpture and "finger painting," practices that were held in low esteem in Chinese aesthetic judgements, as they dispensed with the use of the paintbrush.

The link between the first part and the next is Shanghai, which served many artists as a venue for reciprocal learning and discovery. The second part will easily persuade the readers of Meyer Schapiro's Theory and Philosophy of Arts: Style, Artist, and Society (Georges Braziller Inc., 1994), in which the Columbia University professor explored visuality through several angles - criticism, philosophy, and psychoanalysis, but always proceeding from the image itself - and which distinguishes his enterprise from all abstract generalisations. Clarke plunges into two major questions frequently asked with regards to the difference between Chinese and Western art: first the place of the body and then the issue of abstraction. These two chapters are distinct from each other and yet form, side by side, a coherent whole, since it is calligraphy that is considered the nub of the problematic. Clarke brings to his analysis a deep knowledge of history, using for example the works of Lothar Ledderose on the painter and calligrapher $\mathrm{Mi} \mathrm{Fu}$ (Mi Fu and the Classical Tradition of Chinese Calligraphy, Princeton University Press, 1979); he then uses the exhibitions of the early twentieth century as well as images reproduced in magazines and journals of the era, especially those in Shanghai, which acted as catalysts in the encounters between two modernities, Western and Chinese. Once more, Clarke's pragmatic approach saves him from hasty theorisations. He deciphers new systems of production in the twentieth century (especially the development of studios, not to be confused with the study of literary figures, which left less of a place for production than for reflection). In addition, this part gives the author space to deal with the issue of critical reception. He does this not only in respect of the development of nudes in the 1920s and 1930s in Shanghai, but also, much like Eric de Chassey in the case of the United States, ${ }^{2}$ for the reception of abstraction. The issue of abstraction is again approached through the problematic of calligraphy, as seen 
through the citation of a work of the Hong Kong painter Lui Shou-kwan, Zhuangzi (1974, coll. Hong Kong Museum of Art), whose three categories of motifs complete each other: a column of calligraphic characters that ends with a red seal; thick black ink features resembling calligraphic gestures (especially "flying whites” 飛白feibai); and red butterfly wings. Clarke considers this work to be the culmination of the artist's work in that it reconciles perfect modern abstraction of plane work with the calligraphic space. He deciphers the specifically Chinese mechanism, appropriation of abstraction, including its relation to tradition through the mountain-and-water motif.

In the third part, Clarke focuses on two well-studied cities: Macao and Hong Kong. The author uses their status as buffers to analyse what creates a local identity. Using several visual examples, including photographs, he again brings out the specificity of the object studied. In this last part, one senses the author's personal implication: he has chosen to specify that he lives in Hong Kong and that he therefore has a non-objective view of the city and its close neighbour. This also harks back to his role as a photographer. ${ }^{3}$ The identity question leads on to that of critical reception: Clarke considers the tourism industry an integral part of the visual constitution of Macao's "spectacle." Psychological conclusions could pose problems, such as when Clarke evokes the "hidden anxiety behind the concept of "world city" as regards Hong Kong, if the visual analysis did not come up with an effective rationale. Clarke's work concentrates on visual analysis using concrete examples that constitute proof that Chinese art history is a domain of multiple influences, the process of cultural transfer and acculturation/inculturation being of primary importance.

9 Clarke's objective has been served: proving that Chinese art history must necessarily be integrated with world art history, and not only under the label of "extra-Western," but as actively part and parcel of a constitution of common visual heritage whose most recent experimentations have been largely tributary. Another strength of the book is its emphasis on the analysis of art history as applied to contemporary China. Without rejecting formal analysis and some traditional questionings, art history is a discipline capable of dealing with the complexity of contemporary changes.

10 A review of Clarke's book would be incomplete without mentioning the numerous illustrations, the perfect quality of their reproduction, and their pertinence of choice: the editorial quality of the book adds to the reader's pleasure, especially enhancing understanding of the author's view. In the manner of an exhibition curator, Clarke, offers comparisons of truly interesting images such as the screen shots of Maggie Cheung and Anita Mui, to cite just one example. This visual mastery refines the regard and makes this book a visual experience in itself. Educating the eye, which is the hidden aim behind every good art history work, is achieved here. Finally, with an elaborate index and annotations, the book will be useful both for students and for those who wish to understand the process at work in the history of globalised art. 


\section{NOTES}

1. La Vie et l'œuvre de Su Renshan, rebelle, peintre et fou (The life and works of Su Renshan: Rebel, painter, and madman 1814-1849, English translation by Angharad Pimpaneau), UER Asie orientale, Université Paris 7, 1970.

2. La Peinture efficace. Une histoire de l'abstraction aux États-Unis, 1910-1960 (Efficient painting, a history of abstraction in the United States 1910-1960), Paris, Gallimard, 2001.

3. Exhibitions "The Metropolis - Visual Research into Contemporary Hong Kong" in 1996 at the Hong Kong Art Centre; "A Year in the Life of a City" in 2007 at the University of Hong Kong Museum; "Hong Kong Experience," also in 2007, in Britain.

\section{AUTHORS}

\section{NICOLAS IDIER}

Nicolas Idier is an expert on art history, holding a PhD in history of Chinese art (Paris IV Sorbonne); associate researcher at the Centre for Research on the Far East Paris IV Sorbonne (CREOPS); and cultural attaché (books and intellectual trends) at the French Embassy in China (nicolas.idier@diplomatie.gouv.fr). 